\title{
POST HURRICANE SANDY ENVIRONMENTAL RESTORATION AND RESILIENCY PROJECTS ALONG DELAWARE BAY
}

\author{
Gwen S. Lawrence, Moffatt \& Nichol, glawrence@moffattnichol.com \\ Peter W. Kotulak, Moffatt \& Nichol, pkotulak@moffattnichol.com
}

\begin{abstract}
BACKGROUND
Following Hurricane Sandy, the coastline of the Delaware Bay sustained damage and needed restoration in many areas. The Delaware Department of Natural Resources and Environmental Control (DNREC) received grants as a result of Hurricane Sandy to rehabilitate and improve the functionality, sustainability, and resiliency for several areas along the Delaware Bay shoreline. This paper is a coastal management case study of five of these areas.
\end{abstract}

\section{AREA OF STUDY}

The areas of study reported in this paper are 1) Little River, 2) Little Creek Wildlife Management Area (LCWMA), 3) Ted Harvey Conservation Area (THCA), 4) Swains Beach; and 5) Port Mahon Road, as shown in Figure 1.

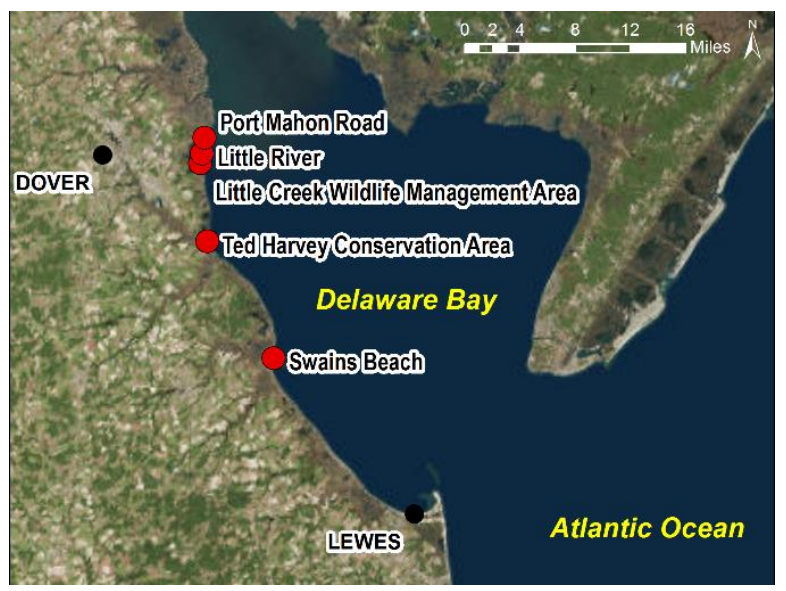

Figure 1 - Areas of study along the Delaware Bay coastline.

\section{LITTLE RIVER}

Over many years the channel for Little River has collected significant sediment limiting the functionally of the federal channel, which was further constrained by morphological changes caused by Hurricane Sandy. The Little River was dredged following an engineering analysis that evaluated different methods of dredging for this purpose including mechanical (clamshell, hydraulic excavator) or hydraulic pipeline dredges. Furthermore, placement alternatives of the dredged material were evaluated to enhance the substrate of the adjacent LCWMA.

\section{LITTLE CREEK WILDLIFE MANAGEMENT AREA}

To restore the substrate of the LCWMA, an engineering analysis of the system was completed. This analysis included a hydrodynamic Delft3D model (Deltares, 2014) that was used to design of new water control structures at two locations to improve management of the water levels in the LCWMA. The existing levee was also restored and raised along with an interior levee. Additionally, a beach restoration was designed and modelled with XBeach (Roelvink, et al., 2015) to provide protection to the LCWMA dune system. Construction of the major water control structure is currently underway.

\section{TED HARVEY CONSERVATION AREA}

At the THCA an existing levee was raised to prevent the tidal flow into and out of the impoundment. In addition, a new water control structure was installed to improve water elevation management to improve resiliency.

\section{SWAINS BEACH}

At Swain's Beach the shoreline consisted of derelict shoreline structures that were evaluated to determine if removal was needed. Furthermore, a conceptual design was completed for the restoration of the shoreline structures. The work was completed and successful in habitat restoration for the horseshoe crabs and migration shorebirds.

\section{PORT MAHON ROAD}

The Port Mahon Road study included evaluating options to construct a long-term, low maintenance protection of the shoreline, restoration of habitat for shorebirds, horseshoe crabs and terrapins, and protection of Port Mahon Road. A main goal of the project was to optimize designs in consideration of all users of the road, shoreline, piers, and marine facilities. The MIKE21 model was used to help optimize the coastal structure design.

\section{CONCLUDING REMARKS}

This set of case studies shows the significant impact of a single storm and the complexity that goes into restoring the shoreline. This paper will include lessons learned and recommendations for future shoreline coastal management to improve resiliency and sustainability.

\section{REFERENCES}

Roelvink, van Dongeren, et al. (2015): XBeach Technical Reference: Kingsday Release, Deltares.

Deltares, "Delft3D-FLOW, User Manual," Delft, 2014. 